\title{
Divergence of Secondary Metabolism in Cell Suspension Cultures and Differentiated Plants of Piper cernuum and P. crassinervium
}

\author{
Ana P. Danelutte ${ }^{a}$, Mara B. Costantin ${ }^{a}$, Guillermo E. Delgado ${ }^{b}$, Raimundo Braz-Filho $^{c}$ \\ and Massuo J. Kato ${ }^{*, a}$ \\ ${ }^{a}$ Instituto de Química, Universidade de São Paulo, 05508-000 São Paulo - SP, Brazil \\ ${ }^{b}$ Universidad Nacional Pedro Ruiz Gallo, Lambayeque, Peru \\ ${ }^{c}$ Universidade do Norte Fluminense, 28013-602 Campos dos Goytacazes - RJ, Brazil
}

\begin{abstract}
Os principais metabólitos secundários das folhas de Piper cernuum são derivados de ácidos cinâmico e di-hidrocinâmicos, além da lignana cubebina. No caso de $P$. crassinervium, há um predomínio de flavonóides, ácidos benzóicos e hidroquinonas preniladas. As culturas celulares de $P$. cernuum produziram as feniletilaminas dopamina e tiramina enquanto que, no caso de $P$. crassinervium, foram isoladas quatro alcamidas, incluindo as novas 2,3,4-trimetoxi- $N$-metilaristolactama e 3-hidroxi-2-metoxi- $N$-metil-aristolactama.
\end{abstract}

The secondary metabolism in the leaves of $P$. cernuum produces cinnamic and dihydrocinnamic acid derivatives and the lignan cubebin. In case of $P$. crassinervium flavonoids and prenylated hydroquinones were characterized as major compounds. The cell cultures showed the production of the phenylethylamines dopamine and tyramine in $P$. cernuum, while in case of $P$. crassinervium four alkamides were isolated as major compounds, including the new 2,3,4trimethoxy- $N$-methyl-aristolactam and 3-hydroxy-2-methoxy- $N$-methyl-aristolactam.

Keywords: Piperaceae, P. cernuum, Piper crassinervium, cell suspension, dihydrocinnamic acid derivatives, cubebin, tyramine, dopamine, aristolactams

\section{Introduction}

The Piper species are mostly tropical plants of worldwide occurrence and are represented by $c a .700$ species. ${ }^{1}$ Their phytochemical investigation have led to the isolation of a number of physiologically active compounds viz. alkaloids/amides, propenylphenols, piperolides, chalcones, dihydrochalcones, flavonoids, prenylated benzoic acid derivatives and lignan/ neolignans. ${ }^{2-12}$ Piper cernuum Vell., an imposing, very large-leave shrub up to $6 \mathrm{~m}$ in height, is widely spread in Amazon, South-eastern and North-eastern regions of Brazil. ${ }^{13}$ Piper crassinervium is a shrub frequently found in Atlantic Forest (Brazil), besides Peru, Colombia and Equador. ${ }^{13}$ Although there is no report for medicinal use of $P$. cernuum and P. crassinervium their phytochemical investigation were undertaken as part of our study of Piperaceae species looking at the search for bioactive compounds, chemosystematic study and also the study of

*e-mail: majokato@iq.usp.br regulatory process of the secondary metabolism that takes place during the differentiation process.

The regeneration or micropropagation of Piper species have been found in literature only for few species such as P. longum, ${ }^{14-16}$, P. colubrinum, ${ }^{17}$ and P. nigrum. ${ }^{18}$ Nevertheless, the establishment of cell suspension cultures and investigation of associated secondary metabolism in Piperaceae species have so far remained untouched. Previous analysis of leaves of $P$. crassinervium have showed the occurrence of antifungal flavanones, benzoic acids and prenylated hydroquinones. ${ }^{10,19}$ The only studies carried out on P. cernuum were addressed to investigate the composition of its essential oil ${ }^{20,21}$ and its antimicrobial activity. ${ }^{22}$ Herein we wish to describe the occurrence of four cinnamic acid derivatives (1-4) together the lignan cubebin (5) in the leaves of P. cernuum. Additionally, its callus and suspension cultures were showed to contain phenylethylamines tyramine (6) and dopamine (7) as major compounds. In case of $P$. crassinervium the major compounds were identified as the aristolactams (8-11), including the new natural product 2,3,4-trimethoxy- $\mathrm{N}$ - 
methyl-aristolactam (10) and 3-hydroxy-3-methoxy- $N$ methyl-aristolactam (11).

\section{Results and Discussion}

Major secondary compounds in leaves of $P$. cernuum were isolated by chromatographic fractionation and were identified as methyl 3,4-dimethoxy-dihydrocinnamate (1),${ }^{6}$ 3,4-dimethoxy-dihydrocinnamic acid (2), ${ }^{6}$ methyl 3,5-dimethoxy-4-hydroxy-dihydrocinnamate (methyl dihydrosynapate, 3$)^{23}$ and methyl 3,5-dimethoxy-4hydroxy-cinnamate (methyl sinapate, 4). ${ }^{24}$ Cubebin $(5)^{3}$ was identified as the sole lignan (Figure 1). The occurrence of dihydrocinnamic acid derivatives, have been previously recorded from other Piper species such as in $P$. lhotzkyanum ${ }^{6}$ while cubebin is quite common. ${ }^{3}$

The callus cultures of P. cernuum was initiated from leaves explants in MS media supplemented with 2,4-D $(0.2$ $\left.\mathrm{mg} \mathrm{mL} \mathrm{L}^{-1}\right)$ and $\mathrm{GA}_{3}\left(0.5 \mathrm{mg} \mathrm{mL}^{-1}\right)$ as growth regulators. In case of $P$. crassinervium the best callus initiation was obtained from shoots using ANA $\left(1.0 \mathrm{mg} \mathrm{mL}^{-1}\right)$ and BAP $\left(0.2 \mathrm{mg} \mathrm{mL}^{-1}\right)$. In both cases the cell suspension developed nicely in liquid media having the same nutrients composition and growth regulators and reached a maximum growth at 26/34 days (Figures 2 and 3), respectively.

HPLC analysis and ${ }^{1} \mathrm{H}$ NMR of extracts from callus and cell suspension cultures (cells and media) of P. cernuun showed the presence of two major compounds that were isolated and identified as tyramine (6) ${ }^{25}$ and dopamine (7). ${ }^{3}$ Their content as dansyl derivatives was determined during the cell growth and increased along the development (Figure 4). Dopamine has been previously identified in Piper amalago $^{3}$ and also in suspension cultures of Mucuna pruriens..$^{26}$ The analysis of the extracts by HPLC indicated that no other alkaloids was produced either in cell, excreted into the liquid media or in the differentiated tissues of the P. cernuum plants. Both phenylethylamines have been frequently found in plants as conjugates such as $\mathrm{N}$-trans (-coumaroyl)-tyramine in $P$. sanctum, ${ }^{27}$ as $\mathrm{N}$-feruroyltyramines in $P$. argyrophylum, ${ }^{28}$ and as $N$-benzoyltyramine

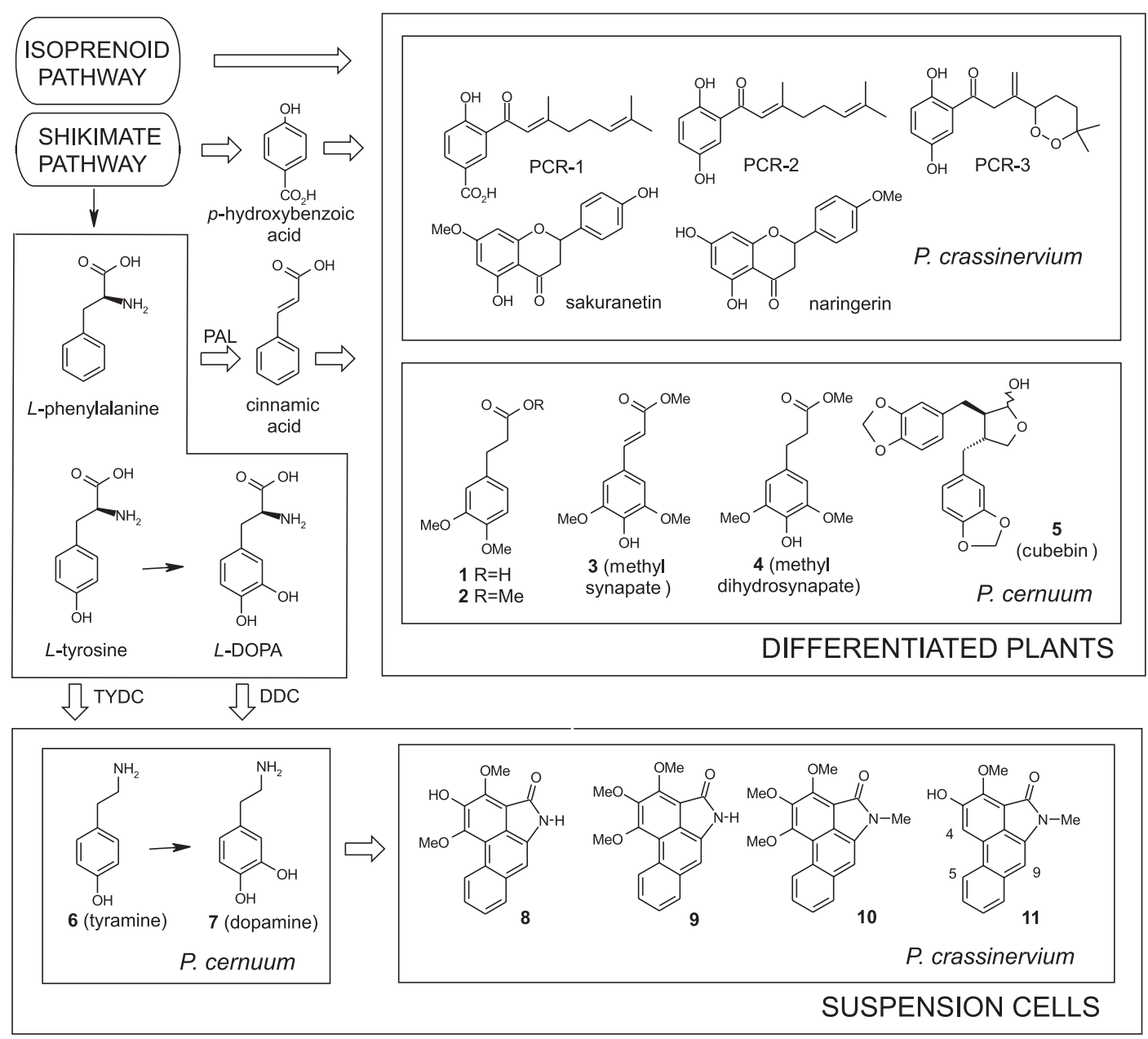

Figure 1. Major secondary metabolites in differentiated tissues and suspension cells of P. cernuum and P. crassinervium and their biosynthetic relationship. PAL: phenylalanine amonia lyase; DDC: dopamine decarboxylase; TYDC: tyrosine decarboxylase; isolated compounds: 1-11 sakuranetin, naringerin, PCR1-3. 


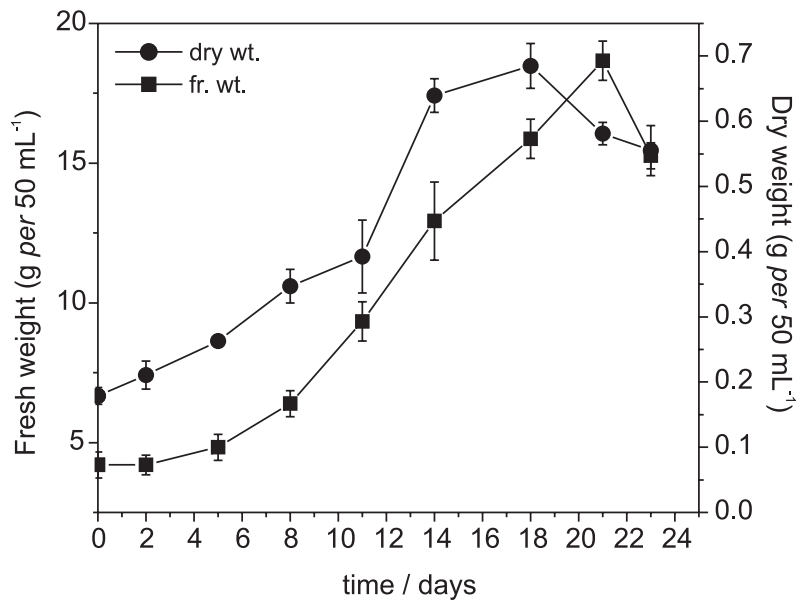

Figure 2. Growth cycle of P. cernuum cell suspension.

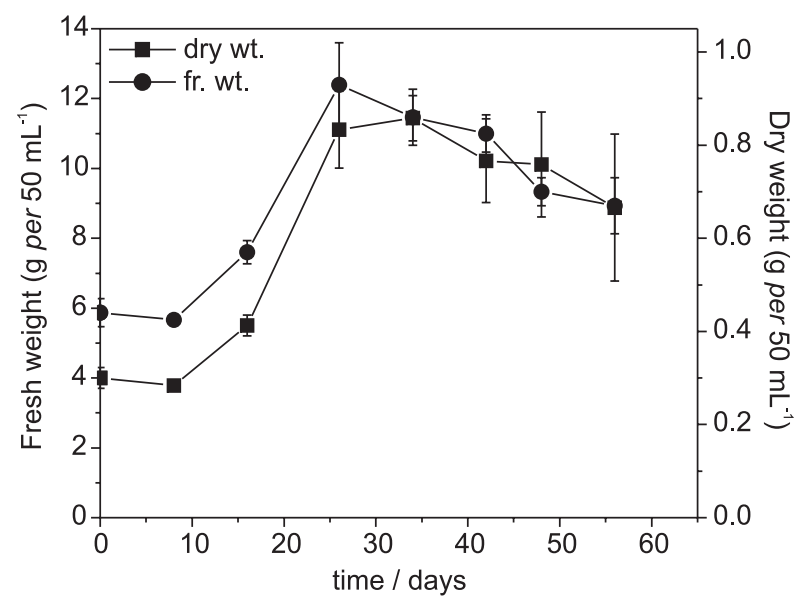

Figure 3. Growth cycle of $P$. crassinervium cell suspension.

in Aniba riparia. ${ }^{25}$ Tyramine amide is wound inducible phytoalexin on tobacco (Nicotiana tabacum) ${ }^{29}$ and is directly involved in the suberization process of wounded potato (Solanum tuberosum). ${ }^{30}$ Together dopamine are important intermediates in the biosynthesis of benzylisoquinoline alkaloids. ${ }^{31}$

The extract from cell suspensions of Piper crassinervium was analyzed by ${ }^{1} \mathrm{H}$ NMR whose signals showed the presence of several methoxyl and aromatic hydrogens. The extract was fractionated by several chromatographic steps yielding four compounds (8-11). Compounds 8 and 9 were identified as goniopedaline $\mathrm{C}$ and piperolactam $\mathrm{C}$, which were previously isolated from Goniothalamus sesquipedalis ${ }^{32}$ and $P$. argyrophylum, $P$. boehimerifolium, $P$. longum, $P$. wightii besides $P$. acutisleginum, ${ }^{33}$ respectively.

Compound $\mathbf{1 0}$ was showed to be has similar spectrometric data as compound $\mathbf{9}$, but was recognized as its $N$-methyl derivative since the ${ }^{1} \mathrm{H}$ and ${ }^{13} \mathrm{C}$ NMR data showed a singlet at $\delta 3.48$ and 26.4, respectively. The molecular ion in the mass spectrum at $\mathrm{m} / \mathrm{z} 323 \mathrm{Da}$ was compatible with the molecular formula $\mathrm{C}_{19} \mathrm{H}_{17} \mathrm{NO}_{4}$.

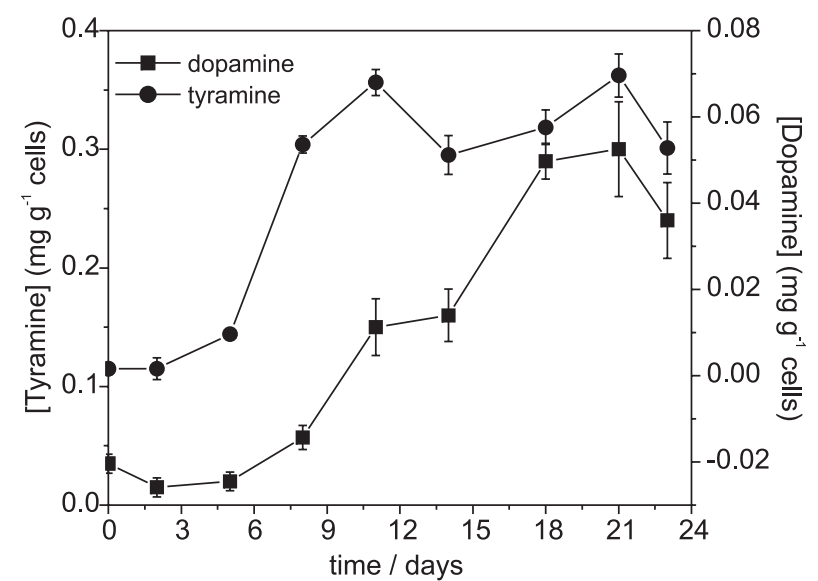

Figure 4. Changes in the content of tyramine and dopamine (determined as dansyl derivatives) during the growth cycle of P. cernuum cell suspension.

All ${ }^{13} \mathrm{C}$ NMR data could be assigned based on the similarities with $\mathbf{9}$, thus $\mathbf{1 0}$ could be determined as 2,3,4trimethoxy- $N$-methyl-aristolactam.

Compound 11 showed a molecular ion at $279 \mathrm{Da}$. Its ${ }^{1} \mathrm{H}$ NMR showed a $N$-methyl signal at 3.49 and a methoxyl group at 4.13 and could be determined as $N$-methyl-3-methyl-cepharanone B by comparison of spectrometric data ${ }^{31}$ and it has not been previously described elsewhere. The determination of two major aristolactams in the suspension cells during the growth curve showed that $\mathbf{9}$ is converted to its $N$-methyl derivative 10 (Figure 5).

Such type of alkaloids groups are relatively restrict in plant kingdom and has been found in Aristolochiaceae, Piperaceae, Annonaceae, Menispermaceae and Monimiaceae species. ${ }^{34}$

The production of phenylethylamines or aristolactams in cell suspension cultures of $P$. cernuum and $P$. crassinervium, respectively, is a metabolic drift that requires the predominance of tyrosine decarboxylase (TYDC) over

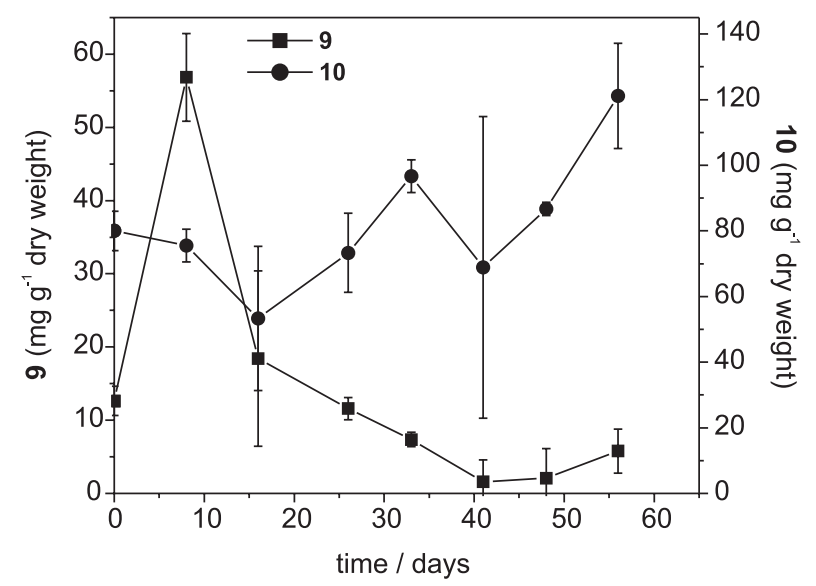

Figure 5. Changes in the content of aristolactams $\mathbf{9}$ and $\mathbf{1 0}$ during the growth of cell suspension of $P$. crassinervium. 
phenylalanine ammonia lyase (PAL). This branch point in the differentiated tissue is followed by additional steps of general phenylpropanoid pathway including the oxidation and methylations steps and/or hydrogenation yielding the cinnamic and dihydrocinnamic acid derivatives in $P$. cernuum. Since only one lignan (cubebin) was isolated, further reductions of cinnamoyl-SCoA esters to the cinnamyl alcohols followed by oxidative coupling to yield lignans are not fully expressed such as in other Piper species. ${ }^{3}$ Such divergence was also observed in suspension cells of $P$. crassinervium, but in this case, phenylethylamines are supposedly consumed in the formation of aristolactams 8-11. Apparently, the Mannich condensation is the limiting step in $P$. cernuum and no aristolactams could be detected in its suspension cells. The modulation of alkaloid metabolism in plant suspension culture of alkaloid-free species have been previously observed. ${ }^{35}$

\section{Experimental}

\section{Instrumental and chromatographic materials}

Silica gel (Merck 230-400 mesh) and Sephadex LH-20 (Pharmacia) were used for column chromatographic separation. Silica gel PF254 (Merck) was used to TLC preparative purification. The NMR spectra (300 and 200 $\mathrm{MHz}$ ) and ${ }^{13} \mathrm{C} \mathrm{NMR}$ (75 and $50 \mathrm{MHz}$ ) were recorded on Bruker DRX-300 using $\mathrm{CDCl}_{3}$ as solvents or otherwise stated and TMS as internal standard. IR spectra were obtained on a FT-IT 510 Nicolet spectrometer. LREIMS were measured at $70 \mathrm{eV}$ on a HP 5990/5988A spectrometer. IR: $\mathrm{KBr}$; EIMS $70 \mathrm{eV}$. HPLC analysis was performed on a HP-1050 using C-18 Econosil, (Alltech) (5 $\mu \mathrm{m}, 250$ X 4.6 $\mathrm{mm}$ column with UV detection at $254 \mathrm{~nm}$.

\section{Plant material}

The specimens of $P$. cernuum and $P$. crassinervium were collected in February 1998, in Núcleo de Picinguaba (Ubatuba), São Paulo, Brazil. Voucher specimens (Cordeiro-1888 and Kato-0084) are deposited at Herbarium of Instituto de Botânica, São Paulo - SP, Brazil.

\section{Isolation of secondary compounds from leaves of $P$. cernuum}

Air-dried and powdered leaves (942 g) were extracted with $\mathrm{MeOH}$. Removal of residual solvent under reduced pressure furnished $137.8 \mathrm{~g}$ of crude extract. Around $90 \mathrm{~g}$ of this extract was suspended in $\mathrm{MeOH}: \mathrm{H}_{2} \mathrm{O}(20 \%)$ and then filtered through celite. The filtered soln was extracted with hexane and then with $\mathrm{CH}_{2} \mathrm{Cl}_{2}$, yielding $\mathrm{CH}_{2} \mathrm{Cl}_{2}$ extract $(8.4 \mathrm{~g})$. Part of this fraction $(3.0 \mathrm{~g})$ was submitted to silica gel $(260 \mathrm{~g}) \mathrm{CC}$. The column was eluted with $\mathrm{CHCl}_{3}$ and $\mathrm{CHCl}_{3}-\mathrm{MeOH}$ 99:01. Frs. 6 to $12(195 \mathrm{mg})$ were pooled and further purified by silica gel $(20 \mathrm{~g}) \mathrm{CC}$ with hexEtOAc gradient furnishing $\mathbf{1}(80 \mathrm{mg})$. From the first column, frs. 14-15 (378 mg) were combined and submitted into silica gel (40 g) CC eluted with hex-EtOAc gradient. The resulting frs. 17-27 (74.8 mg) were subsequently purified by prepared TLC with $\mathrm{CHCl}_{3}-\mathrm{MeOH}(99: 01)$ and yielded 2 (8 mg), 4 (17.0 mg), 3 (5.6 mg) and 5 (5 mg).

3,4-Dimethoxy-dihydrocinnamic acid (1). Amorphous solid $\mathrm{C}_{12} \mathrm{H}_{16} \mathrm{O}_{4}$; IR $v_{\max } / \mathrm{cm}^{-1}: 3500-2500,1701,1505,1464$. LREIMS $m / z$ (rel. int.): $210 \mathrm{M}^{+}$(25), 151 (100), 107 (14), 91 (14), 77 (20).

Methyl 3,4-dimethoxy-dihydrocinnamate (2). Amorphous solid $\mathrm{C}_{12} \mathrm{H}_{16} \mathrm{O}_{4}$; IR $v_{\max } / \mathrm{cm}^{-1}: 1736,1518,1465,3000,2952$, 2836. LREIMS $m / z$ (rel. int.): $224 \mathrm{M}^{+}$(25), 151 (100), 121 (9), 91 (16), 77 (20).

Methyl 3,5-dimethoxy-4-hydroxy-dihydrocinnamate (methyl dihydrosinapate) (3). IR $v_{\max } / \mathrm{cm}^{-1}: 1730,2947$, 2843, 1571, 1432. LREIMS $m / z$ (rel. int.): $238 \mathrm{M}^{+}$(39), 167 (100), 134 (10), 121 (9), 77 (15).

Methyl 3,5-dimethoxy-4-hydroxy-cinnamate (methyl sinapate) (4). IR $v_{\max } / \mathrm{cm}^{-1}: 1730,1571,1432$. LREIMS m/z (rel. int.): $240 \mathrm{M}^{+}$(39), 207 (8), 167 (100), 134 (10), 121 (9), 77 (15).

(-)-Cubebin (5). $[\alpha]_{\mathrm{D}}^{27}-78^{\circ}\left(\mathrm{CHCl}_{3} ; \mathrm{c} 0.2\right) .{ }^{1} \mathrm{H} \mathrm{NMR}: \delta 6.47-$ $6.50(\mathrm{~m}, 6 \mathrm{H}, \mathrm{ArH}), 5.90$ (s, 2H, $\mathrm{O}_{2} \mathrm{CH}_{2}$ ), 5.23 (brs, $1 \mathrm{H}$, H9), 3.82-3.55 (m, 2H, H9'), 2.64-2.40 (m, 4H, 2H7, 2H6), 2.20-2.10 (m, 2H, H8, H8').

\section{Cell suspension cultures of $P$. cernuum}

Leaves obtained from seedlings growing in basic medium Murashigue and Skoog (MS) ${ }^{36}$ were used as explants to initiate callus culture in solid medium containing MS (10.0 $\left.\mathrm{g} \mathrm{L}^{-1}\right)$ supplemented with myoinositol (100.0 $\mathrm{mg} \mathrm{L}^{-1}$ ), thiamine hydrochloride (1.0 mg $\mathrm{L}^{-1}$ ), antioxidant mixture (Sigma A 1179, $50.0 \mathrm{mg} \mathrm{L}^{-1}$ ), sucrose $(2 \%), 2,4-\mathrm{D}\left(0.2 \mathrm{mg} \mathrm{L}^{-1}\right)$, gibberellic acid $\mathrm{GA}_{3}$ $\left(0.5 \mathrm{mg} \mathrm{L}^{-1}\right)$ and agar $(0.17 \%)$. The petri dishes were maintained at $26{ }^{\circ} \mathrm{C}$ under photoperiod of $16 / 8 \mathrm{~h}$. The callus thus obtained were subcultivated every three weeks and transferred to the liquid medium containing MS (10.0 $\left.\mathrm{g} \mathrm{L}^{-1}\right)$, myo-inositol (100.0 $\left.\mathrm{mg} \mathrm{L}^{-1}\right)$, thiamine hydrochloride 
(1.0 mg L $\left.{ }^{-1}\right)$, antioxidant mixture $\left(50.0 \mathrm{mg} \mathrm{L}^{-1}\right)$, sucrose (3\%), 2,4-D $\left(0.2 \mathrm{mg} \mathrm{L}^{-1}\right), \mathrm{GA}_{3}\left(0.5 \mathrm{mg} \mathrm{L}^{-1}\right)$, pyridoxine hydrochloride $\left(0.5 \mathrm{mg} \mathrm{L}^{-1}\right)$, nicotinic acid $\left(0.5 \mathrm{mg} \mathrm{L}^{-1}\right)$, glycine $\left(2.0 \mathrm{mg} \mathrm{L}^{-1}\right)$, casein enzymatic hydrolysate $(250.0$ $\mathrm{mg} \mathrm{L}^{-1}$ ). Cell suspensions were established after 2 or 4 subcultures and have been subcultivated every three weeks.

Isolations of secondary compounds from cells of $P$. cernuит

$30.0 \mathrm{~g}$ of fresh cells were extracted with $\mathrm{MeOH}$ yielding $170 \mathrm{mg}$ of crude extract. The extract was suspended in $\mathrm{H}_{2} \mathrm{O}$ and extracted with $n-\mathrm{BuOH}$. The $n$ - $\mathrm{BuOH}$ fraction $(82.3 \mathrm{mg}$ ) was dissolved in $\mathrm{MeOH}$ and filtered over silanized silica gel to retain the apolar compounds and the yielding fraction $(46 \mathrm{mg}$ ) was subjected to prepared TLC with $\mathrm{CHCl}_{3}-\mathrm{MeOH}$ (7:3) yielding $6(23 \mathrm{mg})$ and $7(15 \mathrm{mg})$.

Tyramine (6). LREIMS $m / z$ (rel. int.): 137 (21), 107 (75), 91 (15), 77 (100), 51 (24). ${ }^{1} \mathrm{H}$ NMR (300 MHz, $\left.\mathrm{CD}_{3} \mathrm{OD}\right)$ : $\delta 7.02(2 \mathrm{H}, \mathrm{d}, 8.5, \mathrm{H} 2, \mathrm{H} 6), 6.68(2 \mathrm{H}, \mathrm{d}, 8.5, \mathrm{H} 3, \mathrm{H} 5)$, $2.90(2 \mathrm{H}, \mathrm{t}, 6.5, \mathrm{H} 7), 2.70(2 \mathrm{H}, \mathrm{t}, 6.5, \mathrm{H} 8) .{ }^{13} \mathrm{C} \mathrm{NMR}$ (CD $\mathrm{OD}): \delta 128.5$ (C1), 130.8 (C2), 116.70 (C3), 157.7 (C-4), 116.7 (C-5), 130.8 (C-6), 33.89 (C-6), 42.3 (C-7).

Dopamine (7). ' ${ }^{1} \mathrm{H}$ NMR (300 MHz, DMSO): $\delta 6.65(1 \mathrm{H}$, $d, J=8.5, \mathrm{H} 5), 6.59$ (1H, d, J=2.1, H2), 6.47 (1H, dd, $J=2.1$, 8.5, H6), 2.90 (2H, t, 6.5, H7), 2.78 (2H, t, 6.5, H8).

\section{Quantification of tyramine and dopamine}

$2.0 \mathrm{~g}$ of fresh cells were extracted and derivatized to dansyl derivatives according to procedure described ${ }^{37}$ but with dihydrochloride putrescine as internal standard. The dansyl derivatives were determined by HPLC as described. ${ }^{38}$ Standard curves of tyramine and dopamine hydrochloride (Sigma) were prepared similarly.

\section{Cell suspension cultures of $P$. crassinervium}

Its seedlings were cultivated in Gamborg B5 media supplemented with mio-inositol (100 $\left.\mathrm{mg} \mathrm{L}^{-1}\right)$, thiamine $\left(1 \mathrm{mg} \mathrm{L}^{-1}\right)$, sucrose $\left(30 \mathrm{~g} \mathrm{~L}^{-1}\right)$, indolacetic acid (AIA) (0.02 $\left.\mathrm{mg} \mathrm{L}{ }^{-1}\right), \mathrm{AG}_{3}\left(0.02 \mathrm{mg} \mathrm{L}^{-1}\right)$ and agar $(0.7 \%)$. The shoots (ca. $1 \mathrm{~cm}$ ) were inoculated in Gamborg B5 media supplemented similarly as before but supplemented with ANA, $\left(1.0 \mathrm{mg} \mathrm{L}^{-1}\right)$, BAP $\left(0.2 \mathrm{mg} \mathrm{L}^{-1}\right)$, and $0.7 \%$ agar. The subculturing of the callus was carried out by regular intervals of 20 days. Cell suspensions cultures of $P$. crassinervium were established by transferring friable callus to the same basal supplemented medium but without addition of agar. The subculturing was performed at intervals of 15-20 days by 2-fold dilution of the cells into fresh medium.

Cell suspensions of 15-20 days of age were used for determination of growth curves. In $50 \mathrm{~mL}$ flasks contained the medium prepared for the cell suspensions, were inoculated $5 \mathrm{~g}$ of fresh weight of $P$. crassinervium cells. This procedure was performed in triplicate. The cells were separated from cell suspensions by vacuum filtration and had their fresh weight determined. Then cells were kept at $50{ }^{\circ} \mathrm{C}$, until constant weight.

\section{Isolation of aristolactams from cells of P. crassinervium}

Cells (100 g of fresh cell) obtained of cell suspensions by vacuum filtration, were extracted with $\mathrm{MeOH}$ under sonication bath (15 min). After elimination of solvent the residue was submitted to EtOAc partition, and concentrated under vacuum to yield the cell extract $(40 \mathrm{mg})$. The extract was purified by preparative TLC (hexane: EtOAc 7:3) to yield four fractions. Fraction 2 was submitted to preparative $\mathrm{TLC}\left(\mathrm{CHCl}_{3}: \mathrm{MeOH} 9: 1\right)$, then by HPLC using a RP-18 column eluted with a gradient $\mathrm{MeOH}: \mathrm{H}_{2} \mathrm{O}$, yielding the aristolactams $\mathbf{8}(1.0 \mathrm{mg})$ and $\mathbf{1 1}(1.1 \mathrm{mg})$. Fractions 3 and 4 consisted of the pure aristolactams 9 $(4.1 \mathrm{mg})$ and $\mathbf{1 0}(5.3 \mathrm{mg})$.

3-Hydroxy-2,4-dimethoxy-aristolactam (goniopedaline, 8). LREIMS $\mathrm{m} / z$ (rel. int.): 295 (83), 280 (48), 266 (12), 252 (26), 237 (10), 209 (17), 164 (10), 153 (22). ${ }^{1} \mathrm{H}$ NMR: $\delta 9.19$ (m, H5), 7.55 (m, 2H, H6, H7), 7.84 (m, H8), 7.19 (s, H9), 4.54 (s, MeO-2), 4.07 (s, MeO-4).

2,3,4-Trimethoxy-aristolactam (piperolactam C, 9). ${ }^{1} \mathrm{H}$ NMR: $\delta 9.19$ (m, H5), 7.52-7.58 (m, 2H, H6, H7), 7.82 (m, 9), 4.52 (s, 3H, MeO-2), 4.20(s, 3H, MeO-3) 4.00 (s, 3H, MeO-4). ${ }^{13} \mathrm{C}$ NMR: $\delta 167.2$ (C1), 157.3 (C2), 154.3 (C3), 146.4 (C4), 116.5 (C4a), 126.6 (C4b, C5), 125.9 (C6), 126.8 (C7), 128.7 (C8), 133.3 (C8a), 106.1 (C9), 63.0 (MeO-2), 61.6, (MeO-3), 60.9 (MeO-4).

2,3,4-Trimethoxy- $N$-methyl-aristolactam (10). LREIMS $\mathrm{m} / \mathrm{z}$ (rel int): 323 (100), 308 (42), 265 (56), 250 (33), 194 (10), 139 (15). ${ }^{1} \mathrm{H}$ NMR: $\delta 9.18$ (m, H5), 7.54 (m, 2H, H6, H7), 7.85 (m, H8), 7.00 (s, H9), 4.54 (s, MeO-2), 4.18 (s, MeO-3), 3.99 (s, MeO-4), 3.49 (s, MeN). ${ }^{13} \mathrm{C}$ NMR: $\delta 165.7$ (C1), 156.8 (C2), 154.0 (C3), 146.4 (C4), 116.1 (C4a), 126.6 (C4b), 126.5 (C5), 125.7 (C6), 127.0 (C7), 128.7 (C8), 133.4 (C8a), 104.5 (C9), 63.0 (MeO2), 61.6, (MeO-3), 60.8 (MeO-4), $26.4(\mathrm{Me}-\mathrm{N})$. 
3-Hydroxy-3-methoxy-N-methyl-aristolactam (11). LREIMS m/z (rel int.): 279 (100), 264 (10), 236 (16), 221(10), 209 (11), 193 (18), 181 (15), 164 (23). ${ }^{1} \mathrm{H}$ NMR: $\delta 7.82$ (s, H4), 7.82 (s, H4), 9.24 (m, H5), 7.56 (m, 2H, H6, H7), 7.81 (m, H8), 7.07 (s, H9), 4.13 (s, MeO-2), 3.49 (s, MeN).

\section{Acknowledgments}

This work was supported by financial aid provided by FAPESP and PADCT. The authors are grateful to CAPES, CNPq and FAPESP for fellowships.

\section{References}

1. Joly, A. B.; Introdução à Taxonomia Vegetal, Nacional: São Paulo, 1985.

2. Jensen, S.; Hansen, J.; Boll, P.M.; Phytochemistry 1993, 33, 523.

3. Parmar, V. S.; Jain, S. C.; Bisht, K. S.; Jain, R.; Taneja, P.; Jha, A.; Tyagi, O. M.; Prasad, A. K.; Wengel, J.; Olsen, C. E.; Boll, P. M.; Phytochemistry 1997, 46, 597.

4. Alécio, A. C.; Bolzani, V. S.; Kato, M. J.; Furlan, M.; J. Nat. Prod. 1998, 61, 637.

5. Baldoqui, D. C.; Kato, M. J.; Cavalheiro, A. J.; Bolzani, V. S.; Young, M. C. M.; Furlan, M.; Phytochemistry 1999, 51, 899.

6. Moreira, D. L.; Guimarães, E. F.; Kaplan, M. A. C.; Phytochemistry 2000, 55, 783.

7. Chaves, M.C.O.; Santos, B.V.O.; Fitoterapia 2002, 73, 547.

8. Navickiene, H. M. D.; Alécio, A. C.; Kato, M.J.; Bolzani, V. S.; Young, M. C.; Cavalheiro, A. J.; Furlan, M.; Phytochemistry 2000, 55, 621.

9. Silva, R. V.; Navickiene, H.M. D.; Kato, M. J.; Bolzani,V. S.; Meda, C.I.; Young, M. C.; Furlan, M.; Phytochemistry 2002 59,521 .

10. Lago, J.G.L.; Ramos, C.S.; Casanova, C.C.D.; Morandim, A. de A.; Bergamo, C.D.; Cavalheiro, A.J.; Bolzani, V. da S.; Furlan, M.; Guimarães, E.F.; Young, M.M.C.; Kato, M. J.; J. Nat. Prod. 2004, 67, 1783.

11. Facundo, V. A.; Sá, A. L.; Silva, S. A. F.; Morais, S. M.; Matos, C. R. R.; Braz-Filho, R.; J. Braz. Chem. Soc. 2004, 15, 140; Dias, L. C.; Chimokomaki, S. B.; Shiota, R. T.; J. Braz, Chem. Soc. 2005, 16, 482.

12. Lago, J. H. G.; Tanizaki, T. M.; Young, M. C. M.; Guimarães, E. F.; Kato, M. J.; J. Braz. Chem. Soc. 2005, 16, 153.

13. Yuncker, T. G.; Hoehnea 1972, 2, 19.

14. Bhat, S.R.; Kackar, A.; Chandel, K.P.S.; Plant Cell Rep. 1992, 11, 525.

15. Bhat, S.R.; Chandel, K.P.S.; Malik, S.K.; Plant Cell Rep. 1995, 14, 398.

16. Soniya, E. V.; Das, M. R.; Plant Cell Tissue Organ Cult. 2002, 70,325 .
17. Kelkar, S.M.; Krishnamurthy, K.V.; Plant Cell Rep. 1998, 17, 721.

18. Philip, V.J.; Joseph, D.; Triggs, G.S.; Dickinson, N.M.; Plant Cell Rep. 1992, 12, 41.

19. Danelutte, A. P.; Lago, J. H. G.; Young, M. C. M.; Kato, M. J.; Phytochemistry 2003, 64, 555.

20. Torquilho, H. S.; Pinto, A. C.; Godoy, R. L. O.; Guimarães, E. F.; J. Essent. Oil Res. 2000, 12, 443.

21. de Abreu, A. M.; Brighente, I. M. C.; de Aguiar, E. M.; Rebelo, R. A.; J. Essent. Oil Res. 2005, 17, 286.

22. Costantin, M. B.; Sartorelli, P.; Limberger, R.; Henriques, A. T.; Steppe, M.; Ferreira, M. J. P.; Ohara, M. T.; Emerenciano, V. P.; Kato, M. J.; Planta Med. 2001, 67, 771.

23. D’Abrosca, B.; DellaGreca, M.; Fiorentino, A.; Monaco, P.; Zarrelli, A.; J. Agric. Food Chem. 2004, 52, 4101.

24. Takaya, Y.; Kondo, Y.; Furukawa, T.; Niwa, M.; J. Agric. Food Chem. 2003, 51, 8061.

25. Barbosa-Filho, J. M.; Yoshida, M.; Gottlieb, O. R.; Rev. Latinoam. Quim. 1990, 21/1, 5.

26. Whickers, H.J.; Visser, J. F.; Huizing, J.J.; Pras, N.; Plant Cell Tissue Org. Cult. 1993, 33, 259.

27. Mata, R.; Morales, I.; Pérez, O.; Rivero-Cruz, I.; Acevedo, L.; Enriquez-Mendoza, I.; Bye, R.; Franzblau, S.; Timmermann, B.; J. Nat. Prod. 2004, 67, 1961.

28. Singh, S.K.; Prasad, A.K.; Olsen, C.E.; Jha, A.; Jain, S.C.; Parmar, V.S.; Wengel, J.; Phytochemistry 1996, 43, 1355.

29. Guillet, G.; de Luca, V.; Plant Physiol. 2005, 137, 692.

30. Borg-Olivier, O.; Monties, B.; Phytochemistry 1993, 32, 601.

31. Facchini, P. J.; Huber-Allanach, K. L.; Tari, L. W.; Phytochemistry 2000, 54, 121.

32. Talapatra, S. K.; Basu, D.; Chattopadhyay, P.; Talapatra, B.; Phytochemistry 1988, 27, 903.

33. Olsen, C.E.; Tyagi, O. D.; Boll, P.M.; Hussaini, F.A.; Parmar, V.S.; Sharma, N.K.; Taneja, P.; Jain, S.C.; Phytochemistry 1993, 33, 518 .

34. Desai, S.J.; Chaturvedi, R.; Mulchandani, N.B.; J. Nat. Prod. 1990, 53, 496.

35. Wink, M.; Witte, L.; FEBS Lett. 1983, 159, 196.

36. Murashigue, T.; Skoog, F.; Plant Physiol. 1962, 15, 473.

37. Eerola, S.; Hinkkanen, R.; Lindfors, E.; Hirvi, T.; J. AOAC Int. 1993, 76, 575.

38. Masson, F.; Talon, R.; Montel, M.C.; Int. J. Food Microbiol. 1996, 32, 199

Received: May 23, 2005

Published on the web: November 24, 2005

FAPESP helped in meeting the publication costs of this article. 